\title{
Competitive strategy selection in the European banking sector using a hybrid decision-making approach $^{* 1}$
}

\author{
Hasan Dinçer ${ }^{2}$, Ozlem Olgu Akdeniz ${ }^{3}$, Umit Hacioglu ${ }^{4}$
}

\begin{abstract}
Strategic planning is an effective tool for long-term planning and utilized by organizations and industries to achieve competitive advantage. Addressing difficulties that the European banking sector struggled during and after the global financial crisis (GFC), the purpose of this paper is to raise important questions about the sustainability of the sector and offers competitive strategy formulations for European policy makers. Empirical findings are accomplished by applying a three phase analysis of SWOT, an integrated model of DEMATEL-ANP (DANP), and fuzzy TOPSIS. Empirical findings from the SWOT analysis suggest a total of twelve factors, which are then incorporated to formulate four strategies. The DANP results illustrate that opportunities dimension has the highest impact and strengths has the lowest among others. The fuzzy TOPSIS results demonstrate that "the European Banking Union (EBU) is expected to remove divergence in the Euro area banking sector" is the most important strategy, whilst "the non-risk based leverage ratio (LR) requirement by Basel III" has the weakest importance among the strategy preferences.
\end{abstract}

Key words: DANP, fuzzy TOPSIS, strategy, competition, European Banking Sector

JEL classification: G20, G21, G41, E44

* Received: 19-10-2017; accepted: 11-06-2018

1 Preliminary version of this paper was presented at the IFABS, 2016 conference on "Risk in Financial Markets and Institutions: New challenges, New solutions" (Barcelona, 1-3 June 2016). We would like to present our special thanks to Maurizio Michael Habib, Thomas Flavin, Yener Altunbas and Nikos Paltalidis for their valuable comments and suggestions.

2 Associate Professor, Istanbul Medipol University, School of Business and Management, Beykoz, 34810, Istanbul, Turkey. Scientific affiliation: banking and insurance. Phone: + 9021244485 44.E-mail: hdincer@medipol.edu.tr (correspondingauthor).

3 Associate Professor, Manchester Metropolitan University, Business School, Manchester, United Kingdom. Scientific affiliation: accounting and financial economics. Phone: +44 (0)161 247 3950.E-mail:o.olgu.akdeniz@mmu.ac.uk.

4 Associate Professor, Istanbul Medipol University, School of Business and Management, Beykoz, 34810, Istanbul, Turkey. Scientific affiliation: business and finance. Phone: + 902124448544. E-mail:uhacioglu@medipol.edu.tr. 


\section{Introduction}

Financial stability and profitability in the European banking industry have increased over the last several years following the latest advances in technology. Financial risks in the European financial services industry have been also managed effectively following the new banking regulations and the implications of the European Central Bank (ECB) monetary policies. As a reflection of increased financial stability and transparency in banking operations, financial markets recovered after sharp losses. In addition to this, introduction of new services in banking industry and the focus on increased customer satisfaction the European banking sector boosted banking profitability and stock prices in capital markets. On the other hand, capital injections into financial services industry in advanced economies boosted capital and investment expenditures in emerging economies increasing GDPs and the other macroeconomic indicators while causing a negative effect on inflation rates. Affinito and Farabullini (2006), Vajanne (2007), and Rughoo and Sarantis (2012) show that while the European banking sector has been integrating, some fragmentations are still inherent due to national characteristics. Initiated with the GFC, Shambaugh (2012) indicates that the EU experienced three interlocking crises as economic recession, which is called 'growth crisis', followed by a banking crisis and finally a sovereign debt crisis.

The GFC started as a subprime crisis in the US during 2007-08, which nearly brought the global banking system to a collapse (Brunnermeier, 2009). European countries were strongly affected from this financial turmoil followed by the Greek and Irish crises, which were translated into a broader Euro zone crisis in 2010. The European sovereign debt crisis is stated to be the result of a strong rise in debt to GDP ratios in the US and Europe (Welfens, 2011). This is not surprising as banks cannot borrow at interest rates below government bond rates and sovereign debt spreads simply creates problems for bank refinancing, particularly in integrated financial markets such as the Euro zone.

Moreover, Euro zone banks experienced low levels of profitability with cost of equity figures higher than return on equity (ROE). Profitability decreased slightly in the last quarter of 2015, which remains well below the levels prior to the GFC. This is followed by an even steeper trend in the second and third quarters partly driven by the Greek sovereign debt crisis. It is suggested that fragilities in the Euro zone banking sector are mainly linked to bank-specific factors such as weak asset quality, high levels of NPLs and country-specific factors, while macro-financial factors have been less effective (ECB, Financial Stability Review, 2015). It can be stated that low interest rates create even lower net interest margins and slow loan growth. In this operating environment, there is a reasonable need to reshape and support banks' business mix and reevaluate their business strategies to achieve sustainable profitability in the medium term. However, risks in implementing new business 
strategies remain in some cases and the speed of such adjustments remains rather uneven.

The EU worked towards a great solution for a stronger monitoring and harmonization of the European banking sector at the EU level, which can be achieved by creating a European Banking Union (EBU). Construction of the EBU may be one of the most significant developments in European integration since the agreement on European Monetary Union (EMU) with the Maastricht Treaty. The EBU was proposed to restore confidence in European banking systems weakened by the GFC and the sovereign debt crisis (Howarth and Quaglia, 2013; Donnelly, 2014). It can be stated that traditional measures such as cost cutting, introducing new regulations or altering product portfolios may not be enough to tackle serious structural problems of the European banking sector. In fact, European banks need fundamental changes and they should transform their business models to the problems accordingly with the help of strategic planning. Banks must develop an effective way to align their strategies with corporate goals on the basis of sustaining profitability ( $\mathrm{Wu}, 2012)$.

In such a volatile environment, European banks are expected to design and implement a perfect competitive strategy. Effective overall business strategy in banking as a competitive weapon provides management superiority over the rivalry and keeps management handling structural weaknesses. Performance management and strategic design are the major pillars of a successful business model. Strategic steps aligning a firm's objectives with its visions are the most important figures if the firm aims to achieve an effective performance management (Schalock and Bonham, 2003; Sridharan et al. 2007). In order to outperform the numerous competitors in the industry, banks should enhance their competitive advantages by improving their internal operational performance (Davis and Albright, 2004; Littler et al., 2000). Moreover, banks should develop an effective way to align their strategies with corporate goals on the basis of performance analyses and a model that links strategic objects as effective improvement paths becomes a critical issue for banks if they are to sustain their competitive advantages (Wu, 2012).

One of the novelties of this paper is the construction and application of an integrated hybrid DANP-fuzzy TOPSIS technique (DANP determines weights of the SWOT factors and the fuzzy TOPSIS selects the best strategy) for multi criteria decision making process of the European banking sector. It introduces a review of related strategy analysis tools that assists in getting a better understanding of forces that play within the European banking sector and environment in which banks operate. In addition, it identifies the best strategies for decision makers using an integrated model of the fuzzy TOPSIS technique with SWOT and DANP. The most important evaluation indicators of strategy formulation are synthesized from the relevant literature and most recent statistics are screened by a committee of experts. Figure A1 illustrates the main phases and steps of the integrated approach. 
The reminder of this paper is organized as follows. The next section defines the competition and strategic roles using SWOT factors for the European Banking Sector. Section 3 reviews the methodology used for estimating the results. Section 4 presents the model construction and the empirical findings, and the final section concludes enclosing some policy implications.

\section{Literature review}

According to the statistics published in the ECB Annual Report (2014), Euro depreciated in particular against the US dollar due to a continuously declining outlook for growth and inflation in the Euro zone from June 2014 onwards, whilst the ECB announced additional monetary policy measures. In the second half of 2014, rising geopolitical stress and worries about the worldwide economic growth augmented problems in the European banking sector. For instance, Euro zone banks have been struggling with weak economic growth, legacy issues from the financial crisis and a strengthened regulatory environment. Despite a recent improvement in bank performance, sustaining profitability growth has been a challenge due to low macroeconomic growth and low interest rates (ECB Financial Stability Review, 2015). Even though changes have been made towards a legal framework that is more helpful for successful non-performing loans (NPLs) in some countries, NPLs have been high and providing new credit to real economy is difficult. Thus, the substantial weight of legacy problem assets remains a very important challenge to banks supplying new credit and requires effective solutions concentrating on remaining fragilities and free up balance sheet capacity for new lending. These recent challenges in the Euro zone could cause some competitive strategies in the European Banking Sector.

The weak economic environment, historically low interest rates, low profitability levels as well as the wave of new regulation and growing risks of competitive interruption have been challenging the European banking sector. Banks need to design new strategies for improving their economics in such a complex environment where structural differences among countries within the EU are still present. For instance, banks in market-based EU countries have larger cross-border assets and liabilities, and derive a larger fraction of their income from fees, rather than interest income, than banks in bank-based EU countries. Traditionally, in Japan and Europe, the role of banks has been much greater than in the US. Moreover, banking assets to GDP ratio are generally larger in the EU than those in Japan or the US. Banking assets in the EU (except Eastern Europe) have increased substantially as a percentage of GDP, contrary to the US and Japan, where the ratio was relatively stable (Bijlsma and Gijsbert, 2013). In terms of bank credit to the private sector as a percentage of GDP, Pozsar et al. (2010) state that Europe and Japan are more bank-based than the US as the ratio is roughly twice the size of that in the US. In addition, there has been a massive growth of bank credit in the EU, except since the 
onset of the financial crisis in 2007, while it has remained more stable over the last decade in the US, and Japan has not been much affected from the crisis.

In such a volatile environment, European banks require good assessment of their strengths and new strategic formulations would help to handle weaknesses. Strategic steps aligning a firm's objectives with its visions are most important if the firm aims to achieve effective performance management (Schalock and Bonham, 2003; Sridharan et al. 2007). Several analysis models are applied to organizational performance measurement for years such as ratio analysis, total production analysis, regression analysis, Delphi analysis, balanced scorecard (BSC), analytic hierarchical process (AHP), analytic network process (ANP), data envelopment analysis (DEA) and Technique for Ordering Preference by Similarity to Ideal Solution (TOPSIS)). These approaches vary regarding their basic concepts, aims, advantages, and disadvantages (Dessler, 2000). Moreover, some structural modeling approaches include Interpretive Structural Modeling (ISM), Decision Making Trial and Evaluation Laboratory (DEMATEL) and Structural Equation Modeling (SEM) (Mahapatra et al., 2015).

In order to outperform the numerous competitors in the industry, banks should enhance their competitive advantages by improving their internal operational performance (Davis and Albright, 2004; Littler et al., 2000). Moreover, banks should develop an effective way to align their strategies with corporate goals on the basis of performance analyses and a model that links strategic objects as effective improvement paths becomes a critical issue for banks if they are to sustain their competitive advantages ( $\mathrm{Wu}, 2012)$. However, there are several studies on the banking competition and strategy in the literature. The main topics of the existing literature highly deal with the economic growth, monetary policies, restrictions, volatility, and international markets. Here are some examples of the recent literature as follows:

In the macroeconomic view, Ruzickova \& Teply (2015) emphasize the theoretical and practical aspects of bank fee and commission income in the European Union. Khan et al. (2016) present the banking competition in the selected ASEAN countries by considering the banks' response to the monetary policy shocks and banking lending channel. Feldmann (2015) defines the banking system concentration and unemployment in developing countries. Fosu (2014) points out the credit information sharing on banking lending and concentration in developing countries. Bremus (2015) studies foreign direct investment and cross-border banking on market concentration and competition. Andrievskaya \& Semenova (2016) examine the bank transparency and concentration with the bank information disclosure requirements on the credit risks.

In the market conditions and restrictions, Shen \& Huang (2003) examine the bank concentration, protection of the creditor, restrictions on banks deal with non-banking 
activities, and bank-based system. Rosen (2007) represent the banking competition with some issues of deposit pricing and antitrust policy. Scott \& Dunkelberg (2010) focus on the small-sized banks have a disadvantage in deposit concentration as the market competition is affected by them positively. Al-Muharrami et al. (2006) study the market structure and the monopolistic competition of Arab banking sector. Liu et al. (2014a) define the banking and non-banking sector competition comparatively.

In the efficiency analysis, Phan et al. (2016) examine the relationship between market concentration, competition and efficiency in emerging banking sector. Chan et al. (2015) analyze the role of market concentration for banking efficiency with Data Envelopment Analysis in Asian economies. Guillén et al. (2014) construct the variables of banking profitability and efficiency for the competitive financial system in Latin America.

In the risk evaluation, Chen et al. (2013) have a concentration measurement considering systematic risk of different sector for the credit portfolios. Park (2009) addresses monopolistically competitive environment in the banking sector. De Haan \& Poghosyan (2012) define the linkages of earnings volatility, size, and concentration in the US banking industry. Bikker \& Haaf (2002) define the competitive market conditions for different kinds of banking industry. Zhang et al. (2013) emphasize the relationship between market concentration, risk-taking behaviors, and performance in the BRIC banks.

One of the most commonly used methods of strategy formulation is the wellknown SWOT (Strenghts, Weaknesses, Opportunities and Threats) analysis, which depends on identification of internal strenghts and weaknesses then matching them with external opportunities and threats to achieve sustainable development (Gilaninia et al. 2012). However, it comes with a disadvantage that the formulated strategies is not supported by quantitative methods and it is '...mainly based on the qualitative analysis, capabilities and expertise of the persons participating in the planning process...' (Pesonen et al., 2001).

Lobriser and Abplanalp (1998) states that a SWOT analysis can be applied with the help of a matrix including the dual strategy combinations of the internal and external factors. Table 1 defines the SWOT factors with the supported literature in order to create a set of strategies for the European Banking Sector. Banks are looking to improve operating profits by controlling costs. Following an improvement in 2014, progress in achieving cost efficiency gains stayed at standstill in the first half of 2015. However, it provides hope as some banks announced cost-cutting targets as part of their restructuring plans, involving a reduction in the retail branch networks by using digital services.

All these have been the dark side, while some opportunities also exist. Firstly, there is considerable room for improving total factor productivity (TFP) growth by developing conditions for innovation, entrepreneurship and labor market 
institutions, and relaxing regulations. Secondly, a growth friendly fiscal policy adjustment is required particularly for those countries that have no fiscal space and need to increase their financial efforts. Thirdly, cutting unproductive spending can provide funds for productive spending and reform efforts should focus on addressing the impact of taxation as well as tax evasion (ECB Annual Report, 2014). Fourthly, loan loss provisions declined since 2012, contributing to better financial performance, particularly, in countries most affected by the financial crisis. In others loan loss provisions are close to pre-crisis levels for the majority of banks, which suggests that falling provisions in these countries are unlikely to lead to significant improvements in profitability in the period ahead. Fifthly, results of the June 2015 EBA risk survey suggest that banks are aware of the need to address IT risks, with increased spending on IT security being the most frequently mentioned response to address these risks, followed by the strengthening of governance, risk culture and business continuity plans. Sixthly, a declining trend has been observed in cost of equity figures since 2012, which may be the outcome of declining stock market risk premium and lower interest rates for risk free assets.

Last but not the least, the Basel Committee on Banking Supervision (BCBS) decided to undertake a major regulatory reform as a response to the GFC, known as the Basel III banking regulations, which introduced of a non-risk-based leverage ratio (LR) requirement alongside the risk-based capital framework. The LR is defined as Tier 1 capital over a bank's total exposure measure, which consists of both on and off-balance-sheet items. The BCBS has been testing a minimum LR of 3\% until 1 January 2017 and is expected to balance the tradeoff between additional loss-absorbing capacity and higher risk-taking associated with an LR requirement. There are various reasons why an LR requirement may be beneficial. Most importantly, highly leveraged banks have lower loss-absorbing capacity and are arguably less resilient to shocks. This is of particular concern if the build-up of excessive leverage concerns the entire banking sector, as witnessed during the financial crisis. The LR may present a better measure for containing aggregate risk and protecting against rare losses in the financial system which are not fully covered under the risk-based capital framework. During the financial crisis, it was observed that highly leveraged banks that experienced failure or distress were still showing strong risk-based capital ratios (BCBS, 2014a; BCBS, 2014b). On the other hand, the main concern relates to the risk-insensitivity of the LR as assets with the same nominal value but of different riskiness are treated equally and face the same capital requirement under the non-risk-based LR (Kiema and Jokivuolle, 2014). SWOT factors have been constructed by considering the recent issues in the Eurozone and strategies derivated from factors have been identified in Table 1. 
Table 1: Strategy Formulations

\begin{tabular}{|l|l|l|}
\hline Strategies & \multicolumn{1}{|c|}{ Direction } & \multicolumn{1}{c|}{ Definitions } \\
\hline Strategy 1 & Decreasing loan loss provisions. & $\begin{array}{l}\text { Basel III LR requirement may boost up the } \\
\text { declining trend in loan loss provisions. }\end{array}$ \\
\hline Strategy 2 & Growth in the banks' ROE. & $\begin{array}{l}\text { Declining cost of equity may help to } \\
\text { elevate the low levels of ROE. }\end{array}$ \\
\hline Strategy 3 & $\begin{array}{l}\text { Cooperation in the banking } \\
\text { sector. }\end{array}$ & $\begin{array}{l}\text { European banking union is expected } \\
\text { to remove divergence in the banking } \\
\text { sectors among countries due to individual } \\
\text { characteristics. }\end{array}$ \\
\hline Strategy 4 & Recovery in bank profitability. & $\begin{array}{l}\text { Low interest rates results in low net interest } \\
\text { margins (low income for banks) which } \\
\text { results in low ROE and low profitability. A } \\
\text { gradual increase in interest rates may help } \\
\text { banks to recover their profitability. }\end{array}$ \\
\hline
\end{tabular}

Source: Authors' own table

In table 1 , we formulate strategy 1 to leverage strength 2 (S2) to maximize opportunity $3(\mathrm{O} 3)$ as the Basel III LR requirement is expected to maximize the declining trend in loan loss provisions. The sovereign debt crisis in Europe had a negative impact on the already declining ROE figures into depressed levels close to zero. As strategy 2 (S3T2), we propose that the declining cost of equity which is identified as one of the strengths of the sector, might help to elevate low levels of ROE. Strategies 3 and 4 handle the weaknesses identified through exploring opportunities and threats, respectively. In strategy 3, we test the importance of establishment of the EBU in removing divergence among the EU countries by combining W3O1. Finally, strategy 4 combines W1T2 proposing that a gradual increase in interest rates may help banks to recover their profitability by achieving higher net interest margins.

\section{Methodology}

\subsection{DEMATEL - based Analytic Network Process (AHP)}

Saaty (1980) introduced the Analytic Hierarchy Process (AHP) to describe multicriteria decision making problems and generalized the method as the Analytic Network Process (ANP) in 1996, which has been widely used in economics and business analytics (Wang and Chen, 2007; Gao and Hailu, 2012; Kutlu and Ekmekcioglu, 2012; Yu et al., 2011). Making a decision by not considering assumptions on the independence of higher-level elements from low level elements is likely to use a generalized ANP approach (Gencer and Gürpinar, 2007). This 
method considers judgments of decision makers and structures weights of criteria in non-hierarchical conditions that have dependencies among directions (Lee and Kim, 2001). Different level hierarchies of network relationships are debated by the ANP feedback approach, in which interdependency between two clusters, named outer dependence, is represented by a two-way arrow or arcs that graphically represent the interdependencies among different levels of criteria. Inner dependencies are represented as a looped arc that indicates interdependencies within the same level of analysis in an ANP approach (Jharkharia and Shankar, 2007; Chung et al., 2005).

There is a wide range of studies in the literature that applied the ANP method such as supplier selection (Gencer and Gürpınar, 2007; Jharkharia and Shankar, 2007; Bayazit, 2006; Sadeghi et al., 2012; Sakthivel et al., 2015), strategy (Yüksel and Dagdeviren, 2007; Shahabi et.al., 2014; Sevkli et al., 2012; Catron et. al., 2013; Wu and Lee, 2007), production (Wolfslehner et at., 2005; Nazir et.al., 2014; Lam, 2015; Kilic et al., 2015; Horenbeek and Pintelon, 2014; Wang and Tzeng, 2012; Vujanovic et al., 2012), and finance and project management (Boj et al., 2014; Chen et al., 2011; Meade and Presley, 2002; Aragones-Beltran et al., 2014; Chen and Li, 2004; Atmaca and Basar, 2012; Yeh and Huang, 2014).

On the other hand, the DEMATEL (Decision Making Trial and Evaluation Laboratory) technique is firstly introduced by the Battelle Research Center in 1972 that examines sophisticated causality structures of real world problems in a hierarchical form and frequently employs complicated objectives by considering interrelations and interactions among the features (Hu et al., 2014; Hsu and Liou, 2013; Hsu et al., 2013; and Liu et al., 2014b). Recently, the DEMATEL is used in different kinds of complicated problems by combining it with other techniques such as the DEMATEL-based ANP (DANP). Some of the DANP applications are technology (Hu et al. 2014), outsourcing (Hsu and Liou, 2013; Hsu et al., 2013), reputation management (Hung, et al., 2012), healthcare industry (Lu et al., 2013), tourism industry (Liu et al., 2012), supplier selection (Hsu, et al., 2012; Liou et al., 2014), criticial infrastructures (Huang et al., 2014), and e-business (Chiu et al., 2013). However, studies related to finance with the integrated DEMATEL technique such as Shen et al. (2014) and Chen et al. (2011) are extremely rare and studies that focus on strategies in financial markets with the application of DANP are almost absent. The novelty of this study is to introduce financial strategies for the European banking sector by applying the DANP approach for the first time. This hybrid technique, DANP, integrates basic features of the ANP and the DEMATEL methods, which considers a total influence matrix, $T$, with basic features of the ANP to rank weights of the criteria. We achieved the empirical analysis by following 8 steps as described by Hu et al. (2014), Hsu, et al. (2012) and Chiu et al. (2013).

Step 1: Construct a direct relation matrix with scales by using questionnaires of experts. Scales from 0 to 4 present the measuring results as no influence (0), low influence (1), middle influence (2), high influence (3), and extreme influence (4), 
respectively. The expert scores are attained to build the pair wise comparisons of dimensions and criteria using the scales.

Step 2: Compute the initial influence matrix $A$ by scores. $A=\left[a_{i j}\right]_{n \times n}$ is constructed by converging expert scores with the direct relation matrix, where $a_{i j}$ represents degree of influence of factor $i$ on factor $j$.

$$
A=\left[\begin{array}{ccccc}
a_{11} & a_{21} & a_{13} & \ldots & a_{1 n} \\
a_{21} & a_{22} & a_{23} & \ldots & a_{2 n} \\
a_{31} & a_{32} & a_{33} & \ldots & a_{3 n} \\
\ldots & \ldots & \ldots & \ldots & \ldots \\
a_{n 1} & a_{n 2} & a_{n 3} & \ldots & a_{n n}
\end{array}\right]
$$

Step 3: Build a normalized direct effect matrix $N$. Values are obtained by normalizing the initial influence matrix with equations (2) and (3).

$$
\begin{aligned}
& N=A / s \\
& \max _{S}=\max \left[1 \leq i \leq n \sum_{J=1}^{n} a_{i j}, 1 \leq j \leq n \sum_{i=1}^{n} a_{i j}\right]
\end{aligned}
$$

Step 4: Construct a total influence matrix $T$ in equation (4), where $I$ is an identity matrix and $\lim _{h \rightarrow \infty} N^{h}=[0]_{n \times n}$.

$$
\begin{aligned}
& T=N+N^{2}+N^{2}+\ldots+N^{h}= \\
& N\left(I+N+N^{2}+\ldots+N^{h-1}\right)(I-N)(I-N)^{-1} \\
& T=N\left(I-N^{h}\right)(I-N)^{-1}=N(I-N)^{-1} \\
& \text { when } \lim _{h \rightarrow \infty} N^{h}=[0]_{n \times n}
\end{aligned}
$$

Step 5: Compute an influential network relation map. Sum of each row and column for $T$ can be provided by equations (5)-(7), where vector $r$ represents the sum of all vector rows $r=\left(r_{1}, \ldots, r_{i}, \ldots, r_{n}\right)$, and vector $y$ indicates the sum of all vector columns $y=\left(y_{1}, \ldots, y_{i}, \ldots, y_{n}\right) . i$ equals $j, i, j \in\{1,2, \ldots, n\},\left(r_{i}-y_{i}\right)$ denotes total degree of the influence among criteria, and the higher is its value, the closer the criterion is to object's central point. $\left(r_{i}-y_{i}\right)$ is the degree of causality among criteria. When $\left(r_{i}-y_{i}\right)$ is positive, it means that criterion $i$ influences other criteria. Otherwise, the criterion is influenced by other criteria.

$$
T=\left[t_{i j}\right]_{n \times n}, i, j=1,2, \ldots, n
$$




$$
\begin{aligned}
& r=\left[\sum_{j=1}^{n} t_{i j}\right]_{n \times 1}=\left(r_{i}\right)_{n \times 1}=\left(r_{1}, \ldots, r_{i}, \ldots, r_{n}\right) \\
& y=\left[\sum_{i=1}^{n} t_{i j}\right]_{n \times 1}^{\prime}=\left(r_{i}\right)_{n \times 1}=\left(r_{1}, \ldots, r_{i}, \ldots, r_{n}\right)
\end{aligned}
$$

Total influence matrix of criteria is $T_{c}=[i, j]_{n \times n}$ and total influence matrix of dimensions or clusters is $T=\left[t_{i j}^{D}\right]_{m \times m}$. Weights and dimensions in the super-matrix of the ANP are determined by normalizing $T_{c}$ to have the dynamic degree of influence of the weights.

Step 6: Develop the unweighted super-matrix $W$. The total influence matrix $T_{c}$ is normalized using dimensions and the normalized matrix $T_{c}^{\beta}$ by dimensions can be determined. The normalized influence matrix $T_{c}^{\beta}$ is transposed to construct the unweighted super-matrix $W$.

Step 7: Calculate the weighted super-matrix $W^{\beta} . T_{D}=\left[t_{i j}^{D}\right]_{m \times m}$, and the total influence matrix is normalized.

Step 8: Limit the weighted super-matrix. Influential weights of the DANP with the limit super-matrix $\lim _{g \rightarrow \infty}\left(W^{\beta}\right)^{g}$ is calculated by multiplying it multiple times to obtain the limit weighted super-matrix to a fixed convergence value, where $g$ represents any number of power.

\subsection{Fuzzy TOPSIS}

The TOPSIS (The Technique for Order of Preference by Similarity to Ideal Solution) method is introduced by Hwang and Yoon (1981), which is a widely known multi-criteria decision method (MCDM) to rank alternatives in different research areas (Hacioglu and Dincer, 2013; Dincer and Hacioglu, 2013; Krohling and Campanharo, 2011; Jiang et al., 2011; Nezhad and Damghani, 2010; Sun, 2010; Tzeng et al., 2005; Abo-Sinna and Amer, 2005; Opricovic and Tzeng, 2004; Olson, 2004; Cheng et al., 2003; Feng and Wang, 2000). Some of the recent application areas of this technique are suppliers (Büyüközkan and Çifçi, 2012; Wang et al., 2009), competition (Torlak et al., 2011; Sun and Lin, 2009), finance (Hacioglu and Dincer, 2013; Dincer and Hacioglu, 2013), manufacturing (Vahdani et al., 2011; Liao, 2003; Jee and Kang, 2000), risk management (Wang and Elhag, 2006), and business intelligence (Rouhani et al. 2012).

TOPSIS considers the shortest and longest distances from the ideal solution to order possible alternatives (Chen and Hwang, 1992; Hwang and Yoon, 1981). Alternative has the longest distance from the negative-ideal solution, while it has the shortest distance from the positive-ideal solution. Accordingly, it is possible to choose the best alternative that has the maximum similarity to the positive-ideal solution (Wang and Chang, 2007; Sun and Lin, 2009). Nevertheless, the fuzzy TOPSIS approach provides more effective results in making decisions under uncertain conditions. This is the reason why Fuzzy TOPSIS method has been increasingly 
conducted in determining the relative importance of criteria and alternatives instead of precise numbers. The fuzzy TOPSIS model can be summarized as:

Step 1: Use the linguistic scales for rating alternatives: Linguistic scales introduced by Chen and Wang (2009), and Chen and Hwang (1992) are used to evaluate the relative importance of alternatives.

Step 2: Construct the fuzzy decision matrix. The matrix is constructed by computing the fuzzy weights for each attribute and ratings of alternatives under each criterion in equations (8) and (9).

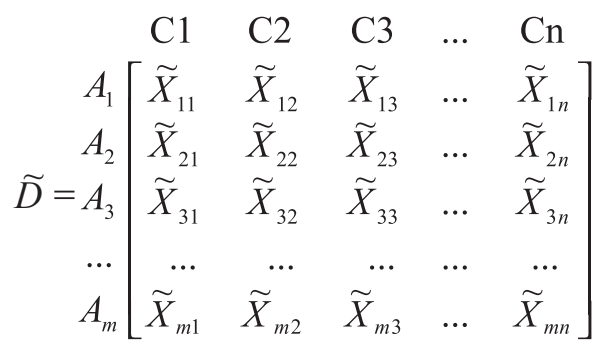

$$
\begin{aligned}
& \widetilde{X}_{i j}=\frac{1}{k}\left(\widetilde{X}_{i j}^{1}+\widetilde{X}_{i j}^{2}+\widetilde{X}_{i j}^{3}+\ldots+\widetilde{X}_{i j}^{k}\right)
\end{aligned}
$$

where $i=1,2,3, \ldots, m$ and $j=1,2,3, \ldots, n ; \widetilde{X}_{i j}^{k}$ is the rating of alternatives provided by the experts.

Step 3: Compute the weighted normalized fuzzy decision matrix: Fuzzy decision matrix is normalized by equations (10) and (11).

$$
\begin{aligned}
\widetilde{r}_{i j} & =\left(\frac{a_{i j}}{c_{i j}^{*}}, \frac{b_{i j}}{c_{i j}^{*}}, \frac{c_{i j}}{c_{i j}^{*}}\right) \\
c_{i j}^{*} & =\sqrt{\sum_{i=1}^{m} c_{i j}^{2}}
\end{aligned}
$$

Normalized fuzzy decision matrix is weighted by multiplying columns of the decision matrix in fuzzy environment with calculated weights.

Step 4: Determine the distance of alternatives from the positive and negative-ideal solution in the fuzzy environment: the fuzzy positive-ideal solution $A^{+}$and the fuzzy negative-ideal solution $A^{-}$are determined by the following equations

$$
A^{+}=\left(\tilde{v}_{1}^{*}, \tilde{v}_{2}^{*}, \tilde{v}_{3}^{*}, \ldots, \tilde{v}_{n}^{*}\right) \text { and } A^{-}=\left(\tilde{v}_{1}^{-}, \widetilde{v}_{2}^{-}, \tilde{v}_{3}^{-}, \ldots, \tilde{v}_{n}\right)
$$

where $\left.\tilde{v}_{j}^{*}=1,1,1\right)$ and $\tilde{v}_{1}^{-}=(0,0,0)$. 
The distances of each alternative from the positive and negative-ideal solution are computed by the formulas:

$$
\begin{aligned}
& D_{i}^{+}=\sum_{j=1}^{n} d\left(\widetilde{v}_{i j}, \widetilde{v}_{j}^{*}\right) \\
& D_{i}^{-}=\sum_{j=1}^{n} d\left(\widetilde{v}_{i j}, \widetilde{v}_{j}^{-}\right)
\end{aligned}
$$

Step 5: Calculate similarities to the ideal solution: the closeness of coefficient is calculated to rank the alternatives by:

$$
C C_{i}=\frac{D_{i}^{-}}{D_{i}^{+}+D_{i}^{-}}
$$

\section{Empirical data and analysis - An application on the European Banking Sector}

\subsection{Hybrid Model Construction}

The integrated model has been built to select the best strategy for the European banking sector by using the DANP technique to determine weights of the SWOT factors followed by the fuzzy TOPSIS technique to select the best strategy. Based on valuable information gathered from the annual reports and financial stability reports published by the ECB over the past ten years, as well as reports from individual Central banks of the EU countries and Europa, among several others, we managed to conduct the empirical analysis.

In the literature, there are several kinds of hybrid approaches to multi-criteria decision making analysis in banking industry. Outstanding examples could be defined as follows: Cinar (2010) provides a decision support model in order to help the bank selecting the most appropriate location for a bank's branch in Turkey using fuzzy AHP and TOPSIS. Sun (2010) develops an evaluation model based on the fuzzy AHP-TOPSIS to help the industrial practitioners for the performance evaluation in a fuzzy environment. The proposed method enables decision analysts to better understand the complete evaluation process and provide a more accurate, effective, and systematic decision support tool. In another study, Secme et al. (2009) propose an integrated fuzzy AHP-TOPSIS model to evaluate the performances of banks. The results show that not only financial performance but also non-financial performance should be taken into account in a competitive environment. Yang et al. (2008) propose a combined DEMATEL-ANP model to solve the dependence and feedback problems to suit real world applications, which has become popular 
in recent research. Wu (2008) also applies a combined DEMATEL-ANP method for identifying a management strategy and stresses the convenience of this combined method. Findings approve that ANP can handle all kinds of interactions systematically and the DEMATEL can handle inner dependences within a set of criteria as well as converting the relations between cause and effect of criteria into a visual structural model. Aksakal and Dagdeviren (2010) introduce an algorithm of DEMATEL-ANP for decision making about the personnel selection. They compute criteria dependence values by using the DEMATEL and solution of the integrated approach is achieved by the ANP method. Kuan and Chen (2014) present an analytical approach for managerial decision making, once again demonstrating that combined DEMATEL-ANP technique can effectively captures interdependences among various aspects and criteria. They emphasize that the combined method has an advantage of considering the hierarchical structure, including interdependence relationships in the condition of flexibly manages the fuzziness situation. Hence, subjectivity, uncertainty and interactivity in expert subjective judgment problems involving complex hierarchical relationships can be solved successfully. With these advantages, the DEMATEL method is used to determine the cause and effect of criteria and to understand the hierarchical structure with interdependence relations; ANP is proposed for application in a hierarchical structure.

In addition to all these models and techniques, there has been a substantial research done on strategy analysis, in particular increasingly in the services sector. Strategy maps have been developed by companies in banking, insurance, manufacturing, healthcare, telecommunications and e-business, as well as nonprofit organizations which have different industry types and sizes (Armitage and Scholey, 2003). According to Banker et al. (2004), strategy maps describe an organization's strategy and can convert intangible assets into tangible outcomes. In this paper, we followed the Industrial Economics Perspective, also known as Bain Mason paradigm, in formulating strategies for the European banking sector. The theory suggests that behavior of firms is influenced by the structure of industry, which in turn determines collective performance of firms in that industry. Structure of the industry relates to demand, the amount of buyers and sellers, barriers of entry and exit, government regulation, taxes, prices and advertising, among other components (Vibert, 2004).

\subsection{Empirical analysis}

We have appointed academicians and experts to build the strategy selection problem and determine the criteria for strategy formulation in this study. Three experts with five years of expertise in European Banking are chosen to discuss the problems and a set of strategies. Then, three academicians constructed the problems and modified strategies based on the expert scales and linguistic variables to evaluate relative importance of the criteria and to select the strategies. The analysis begins with the DANP technique analyzing interactions among four 
dimensions and twelve criteria of the SWOT matrix. A total influence matrix and degree of influence are computed using these scales. Averaged initial directrelationship matrix is obtained by pair wise comparisons in terms of influences and directions among the criteria. Then, total influence matrices of dimensions and criteria are constructed and influential network relation is obtained. Results are illustrated in Table 2 and 3, respectively.

Table 2: Impact-relationship degrees of dimension

\begin{tabular}{|c|c|c|c|c|}
\hline & $r_{i}$ & $y_{i}$ & $\left(r_{i}+y_{i}\right)$ & $\left(r_{i}-y_{i}\right)$ \\
\hline $\mathrm{S}$ & 6.379 & 5.142 & 11.521 & 1.238 \\
\hline $\mathrm{W}$ & 5.008 & 5.848 & 10.856 & -0.839 \\
\hline $\mathrm{O}$ & 5.905 & 5.667 & 11.572 & 0.239 \\
\hline $\mathrm{T}$ & 5.233 & 5.870 & 11.102 & -0.637 \\
\hline
\end{tabular}

Source: Authors' own table

Relationship among the SWOT factors is based on experts scales evaluated by the decision makers. Table 4 presents the column addition vector of the total influence matrix $\left(r_{i}\right)$, the reverse of the addition vector $\left(y_{i}\right)$, the addition of the row and column $\left(r_{i}+y_{i}\right)$ and the difference of row and column $\left(r_{i}-y_{i}\right)$. According to the findings, $r_{i}+y_{i}$ is the highest (11.572) for opportunities (O) indicating that the mutual effects of $\mathrm{O}$ and other dimensions are the greatest, while weaknesses (W) has the lowest (10.856) impact. On the other hand, $r_{i}-y_{i}$ represents the net impact relationship of the total influence matrix, which is 1.238 and greater than zero, suggesting that the impact of strengths $(\mathrm{S})$ on other dimensions is greater than the impact of other dimensions on S. In contrast, row and column difference vector of W (-0.839) and $\mathrm{T}(-0.637)$ are below zero suggesting that the impact of these two dimensions on $\mathrm{S}$ is lower than the impact of $\mathrm{S}$ on these dimensions.

Table 3 presents degree of influence of the criteria. Opportunity 2 has the maximum reason degree (1.617) among the criteria meaning that $\mathrm{O} 2$ most easily influences other criteria. $\mathrm{O} 1$ has the second reason degree in the criteria (1.332). The remaining influence degrees are listed as $\mathrm{W} 3, \mathrm{~T} 1, \mathrm{~T} 2, \mathrm{~W} 2, \mathrm{~T} 3, \mathrm{O} 3$, S3, W1, S1, S2, respectively. This is clear evidence that opportunities have a high influence on other criteria in strategy building. However, strengths have the minimum reason degree with figures below zero $(-1.265,-2.438$ and -0.839 for S1, S2 and S3, respectively). Empirical findings suggest that strengths are most easily influenced by other criteria. We used these constraints in building strategies for the European banking sector. Based on these findings we suggest that policy makers should focus more on opportunities in the sector to improve the already existing strengths further more. 
Table 3: Impact and -relationship degrees of criteria

\begin{tabular}{|c|c|c|c|c|}
\hline & $r_{i}$ & $y_{i}$ & $\left(r_{i}+y_{i}\right)$ & $\left(r_{i}-y_{i}\right)$ \\
\hline $\mathrm{S}_{1}$ & 4.182 & 5.447 & 9.629 & -1.265 \\
\hline $\mathrm{S}_{2}$ & 3.484 & 5.922 & 9.406 & -2.438 \\
\hline $\mathrm{S}_{3}$ & 4.339 & 5.178 & 9.518 & -0.839 \\
\hline $\mathrm{W}_{1}$ & 4.670 & 5.898 & 10.569 & -1.228 \\
\hline $\mathrm{W}_{2}$ & 5.347 & 5.010 & 10.357 & 0.336 \\
\hline $\mathrm{W}_{3}$ & 5.920 & 4.627 & 10.547 & 1.293 \\
\hline $\mathrm{O}_{1}$ & 5.359 & 4.028 & 9.387 & 1.332 \\
\hline $\mathrm{O}_{2}$ & 5.174 & 3.557 & 8.731 & 1.617 \\
\hline $\mathrm{O}_{3}$ & 4.094 & 4.260 & 8.354 & -0.167 \\
\hline $\mathrm{T}_{1}$ & 5.814 & 5.053 & 10.867 & 0.761 \\
\hline $\mathrm{T}_{2}$ & 5.724 & 5.088 & 10.812 & 0.636 \\
\hline $\mathrm{T}_{3}$ & 4.553 & 4.592 & 9.145 & -0.038 \\
\hline
\end{tabular}

Source: Authors' own table

Following, DEMATEL-based ANP technique continues to calculate influential weights of the criteria by computing the un-weighted super-matrix, the weighted super-matrix and the limit super-matrix respectively. Local and global weights of the SWOT factors have been computed using the limit super-matrix. Thus, it is possible to understand relative weights of the dimensions indicated in the SWOT factors and the criteria represent sub-factors of the SWOT matrix based on the DANP method.

We identified that each dimension has similar weights in the SWOT matrix. While threats have the highest weights of the criteria within the dimensions, strengths have the lowest relative weights among the dimensions. Locally, S2, W1, O3, and T2 have the best weights in their own dimensions whereas S3, W3, O2, and T3 have the worst degrees of weights. In the global weights, W1 has the best rank in the weights and S3 has the weakest importance among the SWOT criteria. Local and global weights of the SWOT criteria are very close to each other. W1 has the highest importance (0.379 and 0.098) contrary to S3 (0.314 and 0.072) which has the lowest importance (weight). In general, we may suggest that weaknesses and threats (both negative factors) has higher weights than other dimensions. This might be a clear evidence that $\mathrm{W}$ and $\mathrm{T}$ factors should be more focused on in strategy formulations.

The second phase of the hybrid analysis continues with the Fuzzy TOPSIS technique for ranking the four strategy alternatives. Linguistic variables have been utilized to evaluate the alternative strategies under the fuzzy environment. Following the construction of the fuzzy decision matrix with linguistic evaluations 
provided by the decision makers, normalization process of the matrix has been applied and weighted matrix has been structured with the DANP weight results. Then, the distances of each strategy alternative from the positive and negative ideal solution have been computed to provide the final ranking of strategies. Values of $D_{i}^{+}$and $D_{i}^{-}$and $C C_{i}$ are introduced in Table 4.

Table 4: Values of $D_{i}^{+}$and $D_{i}^{-}$and $\mathrm{CC}_{i}$

\begin{tabular}{|c|c|c|c|c|}
\hline Strategies & $D_{i}^{+}$ & $D_{i}^{-}$ & $C C_{i}$ & Ranking \\
\hline Strategy 1 & 10.806 & 1.285 & 0.106 & 4 \\
\hline Strategy 2 & 10.652 & 1.431 & 0.118 & 2 \\
\hline Strategy 3 & 10.510 & 1.564 & 0.130 & 1 \\
\hline Strategy 4 & 10.710 & 1.378 & 0.114 & 3 \\
\hline
\end{tabular}

Source: Authors' own table

Findings of the Fuzzy TOPSIS method demonstrate that Strategy 3 has the best rank among the alternatives, followed by Strategy 2 and Strategy 4, whilst Strategy 1 has the weakest importance among the strategy preferences.

\section{Results and discussion}

Macroeconomic overview of the European banking sector presented in this paper illustrated that Euro zone banks kept on gaining consistent progress in strengthening their balance sheets and resilience to financial shocks in recent years, regardless they confront challenges due to weak economic growth, legacy issues from the financial crisis and a strengthened regulatory environment. Intensifying difficulties in creating sustainable profitability growth, an extensive amount of legacy problem assets stays in the sector, essentially in those nations most influenced by the global financial crisis. Non-performing loans continue to be high and make it difficult for banks providing new credit to real economy. Although financial performance and capital positions of Euro zone banks slightly improved during 2015, they experience low levels of profitability with cost of equity figures higher than ROE. We would like to state that traditional measures such as cost cutting, introducing new regulations or altering product portfolios may not be enough to tackle serious structural problems of the sector. In fact, European banks need fundamental changes and they should transform their business models to the problems accordingly with the help of strategic planning. In this respect, we formulate and evaluate strategy alternatives in this paper. The methodological novelty is that, we introduce and apply a hybrid model, which combines the DEMATEL, fuzzy ANP and fuzzy TOPSIS approaches to develop strategies. 


\section{Conclusions}

Mastering a perfect business strategy begins with assessing the environmental factors surrounding the business operations and evaluating also internal factors based on their contributions to overall business achievement. Threats and opportunities in external environment are assed by using EFAS (External Factors Analysis) Model while weaknesses and strengths are assessed by IFAS (Internal Factors Analysis). Following both analysis decision makers determine their business objectives, targets and goals based on their priorities in market place. A perfectly designed business strategy and its formulation then turn into a strategy weapon boosting firm's value and increase the stockholders' wealth by maximizing the firm profits in a volatile environment. However, returns or losses in risky decisions depend on the quality of decision making process. The latest advances in technology and quantitative research spotlights the role of hybrid models and scientific applications for the selection of best strategy in decision making process.

Strategy formulation is therefore a necessary toolkit for the long-term planning to achieve competitive advantage. Addressing difficulties that the banking sector in Europe has been struggling since the global financial crisis (GFC), this paper raised serious critiques on the sustainability of the sector and offered a competitive strategy formulation toolkit for decision makers to focus on. Empirical findings have been accomplished by applying a three-phase analysis: (i) SWOT to identify strengths, weaknesses, opportunities and threats, (ii) an integrated model of DEMATELANP (DANP) to determine weights of the SWOT factors, and (iii) fuzzy TOPSIS technique to rank and choose the best strategy. Empirical findings from the SWOT analysis suggested a total of twelve factors, which were then used to formulate four major strategies. The DANP illustrated that opportunities dimension had the highest impact and strengths had the lowest among others. The fuzzy TOPSIS results also demonstrated that "the European Banking Union (EBU) was expected to remove divergence in the Euro area banking sector" was the most important strategy, whilst "the non-risk based leverage ratio (LR) requirement by Basel III" had the weakest importance among the strategy preferences.

\section{References}

A. Abo-Sinna, M., Amer, A. H. (2005) "Extensions of TOPSIS for multi objective large-scale nonlinear programming problems", Applied Mathematics and Computation, Vol. 162, No. 1, pp. 243-256, doi: 10.1016/j.amc.2003.12.087.

Affinito, M., Farabullini, F. (2006) An empirical analysis of national differences in the retail bank interest rates of the euro area, Banca d'Italia Temi di Discussione, Vol. 589, May, doi: 10.2139/ssrn.914508. 
Aksakal, E., Dagdeviren, M. (2010) “ANP ve DEMATEL yöntemleri ile personel seçimi problemine bütünleşik bir yaklaşım”, Journal of Faculty of Engineering Architecture. Gazi University, Vol. 4, No. 25, pp. 905-913.

Al-Muharrami, S., Matthews, K., Khabari, Y. (2006) "Market structure and competitive conditions in the Arab GCC banking system", Journal of Banking \& Finance, Vol. 30, No. 12, pp. 3487-3501, doi: 10.1016/j.jbankfin.2006.01.006.

Andrievskaya, I., Semenova, M. (2016) "Does banking system transparency enhance bank competition? Cross-country evidence", Journal of Financial Stability, SSRN Electronic Journal, pp. 33-50, doi: 10.2139/ssrn.2493083.

Aragonés-Beltrán, P., Chaparro-González, F., Pastor-Ferrando, J.P., Pla-Rubio, A. (2014) “An AHP (Analytic Hierarchy Process)/ANP (Analytic Network Process)-based multi-criteria decision approach for the selection of solarthermal power plant investment projects", Energy, Vol. 66, Mar. pp. 222-238, doi: 10.1016/j.energy.2013.12.016.

Armitage, H.O.W.A.R.D., Scholey, C. (2003) "Mapping mavens", CMA Management, Vol. 77, No. 3, pp. 15-18.

Atmaca, E., Basar, H.B. (2012) "Evaluation of power plants in Turkey using Analytic Network Process (ANP)", Energy, Vol. 44, No. 1, pp. 555-563, doi: 10.1016/j.energy.2012.05.046.

Baele, L., Ferrando, A. Hördahl, P., Krylova, E., Monnet, C. (April 2004) Measuring financial integration in the euro area, ECB Occasional Paper 14.

Banker, R. D., Chang, H., Pizzini, M. J. (2004) "The balanced scorecard: Judgmental effects of performance measures linked to strategy", The Accounting Review, Vol. 79, No. 1, pp. 1-23, doi: 10.2139/ssrn.1456489.

Bayazit, O. (2006) "Use of analytic network process in vendor selection decisions". Benchmarking: An International Journal, Vol 13, No. 5, pp. 566-579, doi: 10.1108/14635770610690410.

BCBS (January 2014a), Basel Committee on Banking Supervision, Basel III leverage ratio framework and disclosure requirements, Bank for International Settlements.

(October 2014b), Basel Committee on Banking Supervision, Basel III: The net stable funding ratio, Bank for International Settlements.

Bijlsma, M.J., Zwart, G.T. (2013) The changing landscape of financial markets in Europe, the United States and Japan, Bruegel working paper (No. 2013/02).

Bikker, J.A., Haaf, K. (2002) "Competition, concentration and their relationship: An empirical analysis of the banking industry", Journal of Banking \& Finance, Vol. 26, No. 11, pp. 2191-2214, doi: 10.1016/s0378-4266(02)00205-4.

Boj, J.J., Rodriguez-Rodriguez, R., Alfaro-Saiz, J.J. (2014) "An ANP-multi-criteriabased methodology to link intangible assets and organizational performance in a Balanced Scorecard context”, Decision Support Systems, Vol. 68, pp. 98-110, doi: 10.1016/j.dss.2014.10.002. 
Bremus, F.M. (2015) "Cross-border banking, bank market structures and market power: Theory and cross-country evidence", Journal of Banking \& Finance, Vol. 50, pp. 242-259, doi: 10.2139/ssrn.2387521.

Brunnermeier, M.K. (2009) "Deciphering the liquidity and credit crunch 20072008", The Journal of economic perspectives, Vol. 23, No. 1, pp. 77-100, doi: $10.3386 / \mathrm{w} 14612$.

Büyüközkan, G., Çifçi, G. (2012) "A novel hybrid MCDM approach based on fuzzy DEMATEL, fuzzy ANP and fuzzy TOPSIS to evaluate green suppliers". Expert Systems with Applications, Vol. 39, No. 3, pp. 3000-3011, doi: 10.1016/j. eswa.2011.08.162

Catron, J.G., Stainback, A., Dwivedi, P., Lhotka, J.M. (2013) "Bioenergy development in Kentucky: A SWOT-ANP analysis", Forest Policy and Economics, pp. 3843, doi: 10.1016/j.forpol.2012.12.003.

Chan, S.G., Koh, E.H., Zainir, F., Yong, C.C. (2015) "Market structure, institutional framework and bank efficiency in ASEAN 5", Journal of Economics and Business, Vol. 82, Nov., pp. 84-112, doi: 10.1016/j.jeconbus. 2015.07.002.

Chen, F.H., Hsu, T.S., Tzeng, G.H. (2011) "A balanced scorecard approach to establish a performance evaluation and relationship model for hot spring hotels based on a hybrid MCDM model combining DEMATEL and ANP", International Journal of Hospitality Management, Vol. 30, No. 4, pp. 908-932, doi: 10.1016/j.ijhm.2011.02.001.

Chen, L., Wang, T.C. (2009) "Optimizing partners' choice in IS/IT outsourcing projects: The strategic decision of fuzzy VIKOR", International Journal of Production Economics, Vol. 120, Jul., pp. 233-242, doi: 10.1016/j.ijpe.2008. 07.022 .

Chen, S.J., Hwang, C.L. (1992), Fuzzy Multiple Attribute Decision Making Methods and Applications, Berlin: Springer, pp. 289-486, doi: 10.1007/978-3-64246768-4_5.

Chen, Y., Wei, X., Zhang, L., Shi, Y. (2013) "Sectoral Diversification and the Banks' Return and Risk: Evidence from Chinese Listed Commercial Banks", Procedia Computer Science, Vol. 18, pp. 1737-1746, doi: 10.1016/j.procs.2013. 05.342.

Cheng, E.W., Li, H. (2004) "Contractor selection using the analytic network process", Construction management and Economics, Vol. 22, No. 10, pp. 10211032, doi: 10.1080/0144619042000202852.

Cheng, S., Chan, C. W., Huang, G.H. (2003) "An integrated multi-criteria decision analysis and inexact mixed integer linear programming approach for solid waste management", Engineering Applications of Artificial Intelligence, Vol. 16, No. 5, pp. 543-554, doi: 10.1016/s0952-1976(03)00069-1.

Chiu, W.Y., Tzeng, G.H., Li, H.L. (2013) “A new hybrid MCDM model combining DANP with VIKOR to improve e-store business", Knowledge-Based Systems, Vol. 37, pp. 48-61, doi: 10.1016/j.knosys.2012.06.017. 
Chung, S.H., Lee, A.H.L., Pearn, W.L. (2005) "Analytic network process (ANP) approach for product mix planning in semiconductor fabricator", International Journal of Production Economics, Vol. 96, pp. 15-36, doi: 10.1016/j. ijpe.2004.02.006.

Cinar, N.T. (2010) "Kuruluş yeri seçiminde bulanık TOPSIS yöntemi ve bankacılık sektöründe bir uygulama", KMÜ Sosyal ve Ekonomik Araştırmalar Dergisi, Vol. 12 , No. 18 , pp. 37-45.

Davis, S., Albright, T. (2004) "An investigation of the effect of the balanced scorecard implementation on financial performance", Management Accounting Research, Vol. 15, No. 2, pp. 135-153, doi: 10.1016/j.mar.2003.11.001

Dessler, G. (2000) Human Resource Management (8th ed.). New Jersey: Prentice Hall.

Dincer, H., Hacioglu, U. (2013) "Performance evaluation with fuzzy VIKOR and AHP method based on customer satisfaction in Turkish banking sector", Kybernetes, Vol. 42, No. 7, pp. 1072-1085, doi: 10.1108/k-02-2013-0021.

Donnelly, S. (2014) "Power politics and the undersupply of financial stability in Europe", Review of International Political Economy, Vol. 21, No. 4, pp. 9801005, doi: 10.1080/09692290.2013.801021.

Draghi, M. (2013) ECB press conference.

ECB Annual Report (2014) Available: http://www.ecb.europa.eu/pub/pdf/annrep/ ar2014en.pdf, accessed May 2016.

ECB Financial Stability Review, Available: https:/www.ecb.europa.eu/pub/pdf/ other/financialstabilityreview201511.en.pdf, accessed November 2015.

Feldmann, H. (2015) "Banking system concentration and unemployment in developing countries", Journal of Economics and Business, Vol. 77, Jan. pp. 60-78, doi: 10.1016/j.jeconbus.2014.08.002.

Feng, C.M., Wang, R.T. (2000) "Performance evaluation for airlines including the consideration of financial ratios", Journal of Air Transport Management, Vol. 6, No. 3, pp. 133-142, doi: 10.1016/s0969-6997(00)00003-x.

Fosu, S. (2014) "Credit information, consolidation and credit market performance: Bank-level evidence from developing countries", International Review of Financial Analysis, Vol. 32, Mar. pp. 23-36, doi: 10.1016/j.irfa.2014.01.002.

Gao, L., Hailu, A. (2012) "Ranking management strategies with complex outcomes: An AHP fuzzy evaluation of recreational fishing using an integrated agentbased model of a coral reef ecosystem", Environmental Modeling and Software, Vol. 31, May, pp. 3-18, doi: 10.1016/j.envsoft.2011.12.00.

Gencer, C., Gürpinar, D. (2007) "Analytic network process in supplier selection: A case study in an electronic firm", Applied Mathematical Modeling, Vol. 31, No. 11, pp. 2475-2486, doi: 10.1016/j.apm.2006.10.002.

Gilaninia, S. et al. (2012) "The role of ICT in performance of small and medium enterprise", Interdisciplanary Journal of Contemporary Research in Business, Vol. 3, No. 10. 
Guillén, J., Rengifo, E.W., Ozsoz, E. (2014) "Relative power and efficiency as a main determinant of banks' profitability in Latin America", Borsa Istanbul Review, Vol. 14, No. 2, pp. 119-125, doi: 10.1016/j.bir.2014.02.003.

Haan, J., De Poghosyan, T. (2012) "Bank size, market concentration, and bank earnings volatility in the US", Journal of International Financial Markets, Institutions and Money, Vol. 22, No. 1, pp. 35-54, doi: 10.1016/j.intfin.2011. 07.002 .

Hacıoğlu, Ü., Dinçer, H. (2013) "Evaluation of conflict hazard and financial risk in the E7 economies' capital markets", Zbornik radova Ekonomskog fakulteta u Rijeci, časopis za ekonomsku teoriju i praksu/Proceedings of Rijeka Faculty of Economics. Journal of Economics and Business, Vol. 31, No. 1, pp. 79-102.

Howarth, D., Quaglia, L. (2013) "Banking union as holy grail: Rebuilding the single market in financial services, stabilizing Europe's banks and completing economic and monetary union", Journal of Common Market Studies, Vol. 51, Aug., pp. 103-123, doi: 10.1111/jcms.12054.

Hsu, C.C., Liou, J.J. (2013) "An outsourcing provider decision model for the airline industry", Journal of Air Transport Management, Vol. 28, pp. 40-46, doi: 10.1016/j.jairtraman.2012.12.009.

Hsu, C.C., Liou, J.J., Chuang, Y.C. (2013) "Integrating DANP and modified grey relation theory for the selection of an outsourcing provider", Expert Systems with Applications, Vol. 40, No. 6, pp. 2297-2304, doi: 10.1016/j.eswa.2012.10.040.

Hsu, C.H., Wang, F.K., Tzeng, G.H. (2012) "The best vendor selection for conducting the recycled material based on a hybrid MCDM model combining DANP with VIKOR. Resources", Conservation and Recycling, Vol. 66, Sep., pp. 95-111, doi: 10.1016/j.resconrec.2012.02.009.

Hu, S.K., Lu, M.T., Tzeng, G.H. (2014) "Exploring smart phone improvements based on a hybrid MCDM model", Expert Systems with Applications, Vol. 41, No. 9, pp. 4401-4413, doi: 10.1016/j.eswa.2013.12.052.

Huang, C.N., Liou, J.J., Chuang, Y.C. (2014) "A method for exploring the interdependencies and importance of critical infrastructures", Knowledge-Based Systems, Vol. 55, pp. 66-74, doi: 10.1016/j.knosys.2013.10.010.

Hung, Y.H. et al. (2012) "Online reputation management for improving marketing by using a hybrid MCDM model”, Knowledge-Based Systems, Vol. 35, pp. 8793, doi: 10.1016/j.knosys.2012.03.004.

Hwang, C.L., Yoon, K. (1981) Multiple Attributes Decision Making Methods and Applications. Berlin Heidelberg: Springer, doi: 10.1007/978-3-642-4831893.

Jee, D.H., Kang, K.J. (2000) "A method for optimal material selection aided with decision making theory”, Materials and Design, Vol. 21, pp. 199-206, doi: 10.1016/s0261-3069(99)00066-7. 
Jharkharia, S., Shankar, R. (2007) "Selection of logistics service provider: An analytic network process (ANP) approach", Omega, Vol. 35, pp. 274 - 289, doi: 10.1016/j.omega.2005.06.005.

Jiang, J., Chen, Y.W., Chen, Y.W., Yang, K. (2011) "TOPSIS with fuzzy belief structure for group belief multiple criteria decision making", Expert Systems with Applications, Vol. 38, pp. 9400-9406, doi: 10.1016/j.eswa.2011.01.128.

Khan, H.H., Ahmad, R.B., Gee, C.S. (2016) "Bank competition and monetary policy transmission through the bank lending channel: Evidence from ASEAN", International Review of Economics \& Finance, Vol. 44, pp. 19-39, doi: 10.1016/j.iref.2016.03.003.

Kiema, I., Jokivuolle, E. (2014) "Does a Leverage Ratio Requirement Increase Bank Stability?", Journal of Banking and Finance, Vol. 39, No. 1, pp. 240-254, doi: 10.1016/j.jbankfin.2013.11.009.

Kilic, H., Zaim, S.S., Delen, D. (2015) "Selecting 'The Best ERP system for SMEs using a combination of ANP and PROMETHEE methods", Expert Systems with Applications Vol. 42, pp. 2343-2352, doi: 10.1016/j.eswa.2014.10.034.

Krohling R.A., Campanharo, V.C. (2011) "Fuzzy TOPSIS for group decision making: A case study for accidents with oil spill in the sea", Expert Systems with applications, Vol. 38, No. 4, pp. 4190-4197, doi: 10.1016/j.eswa.2010. 09.081 .

Kuan, M., Chen, Y. (2014) "A hybrid MCDM framework combined with DEMATEL-based ANP to evaluate enterprise technological innovation capabilities assessment", Decision Science Letters, Vol. 3, No. 4, pp. 491-502, doi: $10.5267 /$ j.dsl.2014.6.003.

Kutlu, A.C., Ekmekçioglu, M. (2012) "Fuzzy failure modes and effects analysis by using fuzzy TOPSIS-based fuzzy AHP”, Expert Systems with Applications, Vol. 39, pp. 61-67, doi: 10.1016/j.eswa.2011.06.044.

Lam, J.S.L. (2015) "Designing a sustainable maritime supply chain: A hybrid QFDANP approach", Transportation Research Part E, Vol. 78, pp. 70-81, doi: 10.1016/j.tre.2014.10.003.

Lee, J.W., Kim, S.H. (2001) "An integrated approach for interdependent information system project selection", International Journal of Project Management, Vol. 19, No. 2, pp. 111-118, doi: 10.1016/s0263-7863(99)00053-8.

Liao, H.C. (2003) "Using PCR-TOPSIS to optimize Taguchi's multi-response problem", The International Journal of Advanced Manufacturing Technology, Vol. 22, pp.649-655, doi: 10.1007/s00170-002-1485-x.

Liou, J.J., Chuang, Y.C. Tzeng, G.H. (2014) "A fuzzy integral-based model for supplier evaluation and improvement", Information Sciences, Vol. 266, pp. 199-217, doi: 10.1016/j.ins.2013.09.025.

Littler, K., Aisthorpe, P., Hudson, R., Keasey, K. (2000) “A new approach to linking strategy formulation and strategy implementation: An example from the UK 
banking sector", International Journal of Information Management, Vol. 20, No. 6, pp. 411-428, doi: 10.1016/s0268-4012(00)00036-0.

Liu, C.H., Tzeng, G.H., Lee, M.H. (2012) "Improving tourism policy implementation - The use of hybrid MCDM models", Tourism Management, Vol. 33, No. 2, pp. 413-426, doi: 10.1016/j.tourman.2011.05.002.

Liu, G., Mirzaei, A., Vandoros, S. (2014a) "The impact of bank competition and concentration on industrial growth", Economics Letters, Vol. 124, No. 1, pp. 60-63, doi: 10.1016/j.econlet.2014.04.016.

Liu, H.C. You, J.X., Zhen, L., Fan, X.J. (2014b) "A novel hybrid multiple criteria decision making model for material selection with target-based criteria", Materials and Design, Vol. 60, pp. 380-390, doi: 10.1016/j.matdes.2014.03.071.

Lobriser, R., Abplanalp, P.A. (1998) Strategisches management. Visionen entwickeln. Strategien umsetzen. Erfolgspotentiale aufbauen. Zürich: Versus, 468.

Lu, M.T., Lin, S.W., Tzeng, G.H. (2013) “Improving RFID adoption in Taiwan's healthcare industry based on a DEMATEL technique with a hybrid MCDM model", Decision Support Systems, Vol. 56, pp. 259-269, doi: 10.1016/j.dss. 2013.06.006.

Mahapatra, B. Mukherjee, K., Bhar, C. (2015) "Performance Measurement-An DEA-AHP Based Approach", Journal of Advanced Management Science, Vol. 3, No. 1, doi: 10.12720/joams.3.1.26-30.

Meade, L.M., Presley, A. (2002) "R\&D project selection using the analytic network process", IEEE Transactions on Engineering Management, Vol. 49, No. 1, pp. 59-66, doi: 10.1109/17.985748.

Nazir, S. et al. (2014) "Software Component Selection Based on Quality Criteria Using the Analytic Network Process" Abstract and Applied Analysis, pp. 1-12, doi: $10.1155 / 2014 / 535970$.

Nezhad, S.S., Damghani, K.K. (2010) "Application of a fuzzy TOPSIS method base on modified preference ratio and fuzzy distance measurement in assessment of traffic police centers performance", Applied Soft Computing, Vol. 10, pp. 1028-1039, doi: 10.1016/j.asoc.2009.08.036.

Olson, D.L. (2004) "Comparison of weights in TOPSIS models", Mathematical and Computer Modelling, Vol. 40, pp. 721-727, doi: 10.1016/j.mcm.2004. 10.003 .

Opricovic, S., Tzeng, G.H. (2004) "Compromise solution by MCDM methods: A comparative analysis of VIKOR and TOPSIS", European Journal of Operational Research, Vol. 156, pp. 445-455, doi: 10.1016/s0377-2217(03) 00020-1.

Park, K.H. (2009) "Has bank consolidation in Korea lessened competition?", The Quarterly Review of Economics and Finance, Vol. 49, No. 2, pp. 651-667, doi: 10.1016/j.qref.2008.02.003. 
Pesonen, M.M. et al. (2001) “Assessing the priorities using A'WOT among resource management strategies at the Finnish forest and park service", For Science, Vol. 47, No. 4, pp. 534-541, doi: 10.1007/978-94-015-9799-9_12.

Phan, H.T., Daly, M.K., Akhter, S. (2016) "Bank efficiency in emerging Asian countries", Research in International Business and Finance, Vol. 38, pp. 517-530, doi: 10.1016/j.ribaf.2016.07.012.

Pozsar, Z., Adrian, T., Ashcraft, A.B. Boesky, H. (2010) Shadow banking, Federal Reserve Bank of New York Staff Reports, doi: 10.2139/ssrn.1645337.

Rosen, R.J. (2007) "Banking market conditions and deposit interest rates", Journal of Banking \& Finance, Vol. 31, No. 12, pp. 3862-3884, doi: 10.1016/j.jbankfin. 2007.02.009.

Rouhani, S., Ghazanfari, M., Jafari, M. (2012) "Evaluation model of business intelligence for enterprise systems using fuzzy TOPSIS", Expert Systems with Applications, Vol. 39, pp. 3764-3771, doi: 10.1016/j.eswa.2011.09.074.

Rughoo, A., Sarantis, N. (2012) "Integration in European retail banking: Evidence from savings and lending rates to non-financial corporations", Journal of International Financial Markets. Institutions and Money, Vol. 22, No. 5, pp. 1307-1327, doi: 10.1016/j.intfin.2012.08.001.

Růžičková, K., Teplý, P. (2015) “Are Bank Fees in the Czech Republic Excessive?”, Procedia Economics and Finance, Vol. 25, pp. 264-277, doi: 10.1016/s22125671(15)00737-6.

Saaty, T.L. (1996) Decision making with dependence and feedback: The analytic network process, Pitssburgh: RWS Publication, doi: 10.4018/9781591407027.ch018.

Saaty, T.L. (1980) The Analytic Hierarchy Process. New York: McGraw-Hill.

Sadeghi, M., Rashidzadeh, M.A., Soukhakian, M.A. (2012) "Using Analytic Network Process in a Group Decision-Making for Supplier Selection", Informatica, Vol. 23, No. 4, pp. 621-643, doi: 10.1287/serv.1120.0024.

Sakthivel, G., Ilangkumaran, M., Gaikwad, A. (2015) "A hybrid multi-criteria decision modelling approach for the best biodiesel blend selection based on ANP-TOPSIS analysis", Ain Shams Engineering Journal, Vol. 6, pp. 239-256, doi: 10.1016/j.asej.2014.08.003.

Schalock, R.L., Bonham, G.S. (2003) "Measuring outcomes and managing for results", Evaluation and Program Planning, Vol. 26, No. 3, pp. 229-235, doi: 10.1016/s0149-7189(03)00027-2.

Scott, J.A., Dunkelberg, W.C. (2010) "Competition for small firm banking business: Bank actions versus market structure", Journal of Banking \& Finance, Vol. 34, No. 11, pp. 2788-2800, doi: 10.1016/j.jbankfin.2010.06.004.

Seçme, N., Bayrakdaroğlu, Y.A., Kahraman, C. (2009) "Fuzzy performance evaluation in Turkish banking sector using analytic hierarchy process and TOPSIS", Expert Systems with Applications, Vol. 36, No. 9, pp. 11699-11709, doi: 10.1016/j.eswa.2009.03.013. 
Sevkli, M. et al. (2012) "Development of a fuzzy ANP based SWOT analysis for the airline industry in Turkey", Expert Systems with Applications, Vol. 39, No. 1, pp. 14-24, doi: 10.1016/j.eswa.2011.06.047.

Shahabi, R. et al. (2014) "An ANP-SWOT approach for interdependency analysis and prioritizing the Iran' s steel scrap industry strategies", Resources Policy, Vol. 42, pp. 18-26, doi: 10.1016/j.resourpol.2014.07.001.

Shambaugh, J.C. (2012) "The Euro's three crises". Brookings Papers on Economic Activity. Spring, pp. 157-211, doi: 10.1353/eca.2012.0006.

Shen, C.H., Huang, A.H. (2003) "Are performances of banks and firms linked?", Journal of Policy Modeling, Vol. 53, no. 15, pp. 1-18, doi: 10.1016/s01618938(03)00012-7.

Shen, K.Y., Yan, M.R. Tzeng, G.H. (2014) "Combining VIKOR-DANP model for glamor stock selection and stock performance improvement", KnowledgeBased Systems, Vol. 58, pp. 86-97, doi: 10.1016/j.knosys.2013.07.023.

Sridharan, S. et al. (2007) "Analysis of strategic plans to assess planning for sustainability of comprehensive community initiatives", Evaluation and Program Planning, Vol. 30, No. 1, pp. 105-113, doi: 10.1016/j.evalprogplan. 2006.10.006.

Sun, C.C. (2010) "A performance evaluation model by integrating fuzzy AHP and fuzzy TOPSIS methods", Expert Systems with Applications, Vol. 37, pp. 77457754, doi: 10.1016/j.eswa.2010.04.066.

Sun, C.C., Lin, G.T.R. (2009) "Using fuzzy TOPSIS method for evaluating the competitive advantages of shopping websites", Expert Systems with Applications, Vol. 36, pp. 11764-11771, doi: 10.1016/j.eswa.2009.04.017.

Torlak, G., Sevkli, M., Sanal, M., Zaim, S. (2011) “Analyzing business competition by using fuzzy TOPSIS method: An example of Turkish domestic airline industry", Expert Systems with Applications, Vol. 38, pp. 3396-3406, doi: 10.1016/j.eswa.2010.08.125.

Tzeng, G.H., Lin, C.W., Opricovic, S. (2005) "Multi-criteria analysis of alternative fuel buses for public transportation", Energy Policy, Vol. 33, pp. 1373-1383, doi: 10.1016/j.enpol.2003.12.014.

Vahdani, B., Mousavi, S.M., Tavakkoli-Moghaddam, R. (2011) "Group decision making based on novel fuzzy modified TOPSIS method", Applied Mathematical Modelling, Vol. 35, pp. 4257-4269, doi: 10.1016/j.apm.2011.02.040.

Vajanne, L. (2007) Integration in euro area retail banking markets-convergence of credit interest rates, Bank of Finland Research Discussion Paper No. 27, doi: 10.2139/ssrn. 1081564.

Van Horenbeek, A., Pintelon, L. (2014) "Development of a maintenance performance measurement framework-using the analytic network process (ANP) for maintenance performance indicator selection", Omega, Vol. 42, No. 1, pp. 3346, doi: 10.1016/j.omega.2013.02.006. 
Vibert, F. (2004) The EU's New System of Regulatory Impact Assessment - A Scorecard. London: European Policy Forum.

Vujanović, D. et al. (2012) "Evaluation of vehicle fleet maintenance management indicators by application of DEMATEL and ANP", Expert Systems with Applications, Vol. 39, No. 12, pp. 10552-10563, doi: 10.1016/j.eswa.2012. 02.159 .

Wang, J.W., Cheng, C.H., Cheng, H.K. (2009) "Fuzzy hierarchical TOPSIS for supplier selection", Applied Soft Computing, Vol. 9, pp. 377-386, doi: 10.1016/ j.asoc.2008.04.014.

Wang, T.C., Chang, T.H. (2007) "Application of TOPSIS in evaluating initial training aircraft under a fuzzy environment", Expert Systems with Applications, Vol. 33, pp. 870-880, doi: 10.1016/j.eswa.2006.07.003.

Wang, T.C., Chen, Y.H. (2007) "Applying consistent fuzzy preference relations to partnership selection", International Journal of Management Science, Vol. 35, pp. 384-388, doi: 10.1016/j.omega.2005.07.007.

Wang, Y.L., Tzeng, G.H. (2012) "Brand marketing for creating brand value based on a MCDM model combining DEMATEL with ANP and VIKOR methods", Expert Systems with Applications, Vol. 39, No. 5, pp. 5600-5615, doi: 10.1016/j. eswa.2011.11.057.

Wang, Y.M., Elhag, T.M.S. (2006) "Fuzzy TOPSIS method based on alpha level sets with an application to bridge risk assessment", Expert Systems with Applications, Vol. 31, pp. 309-319, doi: 10.1016/j.eswa.2005.09.040.

Welfans, P.J.J. (2011) "From the Transatlantic Banking Crisis to the Euro Crisis?", International Economic Policy, Vol. 8, pp. 15-29, doi: 10.1007/s10368-011-0187-y.

Wolfslehner, B., Vacik, H., Lexer, M.J. (2005) "Application of the analytic network process in multi-criteria analysis of sustainable forest management", Forest Ecology and Management Vol. 207, No. 1, pp. 157-170, doi: 10.1016/j.foreco. 2004.10.025.

Wu, W.W. (2008) "Choosing knowledge management strategies by using a combined ANP and DEMATEL approach", Expert Systems with Applications, Vol. 35, pp. 828-835, doi: 10.1016/j.eswa.2007.07.025.

Wu, W.W., Lee, Y.T. (2007) "Selecting knowledge management strategies by using the analytic network process", Expert systems with Applications, Vol. 32, No. 3, pp. 841-847, doi: 10.1016/j.eswa.2006.01.029.

Wu, H.Y. (2012) "Constructing a strategy map for banking institutions with key performance indicators of the balanced scorecard", Evaluation and Program Planning, Vol. 35, No. 3, pp. 303-320, doi: 10.1016/j.evalprogplan.2011.11.009.

Yang, Y.P.O., Shieh, H.M., Leu, J.D., Tzeng, G.H. (2008) “A novel hybrid MCDM model combined with DEMATEL and ANP with applications", International Journal of Operations Research, Vol. 3, No. 5, pp. 160-168, doi: 10.1016/j. eswa.2010.07.048. 
Yeh, T.M., Huang, Y.L. (2014) "Factors in determining wind farm location: Integrating GQM, fuzzy DEMATEL, and ANP”, Renewable Energy, Vol. 66, pp. 159-169, doi: 10.1016/j.renene.2013.12.003.

Yu, X., Guo, S., Guo, J., Huang, X. (2011) "Rank B2C e-commerce websites in e-alliance based on AHP and fuzzy TOPSIS", Expert Systems with Applications, Vol. 38, pp. 3550-3557, doi: 10.1016/j.eswa.2010.08.143.

Yüksel, İ., Dagdeviren, M. (2007) "Using the analytic network process (ANP) in a SWOT analysis-A case study for a textile firm", Information Sciences, Vol. 177, No. 16, pp. 3364-3382, doi: 10.1016/j.ins.2007.01.001.

Zhang, J., Jiang, C., Qu, B., Wang, P. (2013) "Market concentration, risk-taking, and bank performance: Evidence from emerging economies", International Review of Financial Analysis, Vol. 30, pp. 149-157, doi: 10.1016/j.irfa.2013. 07.016. 


\title{
Odabir konkurentskih strategija u europskom bankarskom sektoru primjenom pristupa hibridnog odlučivanja ${ }^{1}$
}

\author{
Hasan Dinçer ${ }^{2}$, Ozlem Olgu Akdeniz ${ }^{3}$, Umit Hacioglu
}

\begin{abstract}
Sažetak
Strateško planiranje je učinkovit alat za dugoročno planiranje koje primjenjuju organizacije $i$ industrije za postizanje konkurentske prednosti. S obzirom na poteškoće s kojima se europski bankarski sektor suočava za vrijeme $i$ nakon globalne financijske krize (GFC), svrha ovog rada je podići važna pitanja o održivosti sektora $i$ ponuditi formulacije konkurentnih strategija za europske kreatore politike. Empirijski rezultati postižu se primjenom SWOT analize u tri faze, integriranog modela DEMATEL-ANP (DANP) i 'fuzzy' (neizrazitog) TOPSIS-a. Empirijski rezultati SWOT analize ukazuju na ukupno dvanaest čimbenika, koji su potom uključeni u formuliranje četiri strategije. DANP rezultati potvrđuju da faktor prilika ima najveći utjecaj, a snage imaju najniži utjecaj u odnosu na ostala tri faktora. Neizraziti rezultati TOPSIS-a pokazuju da najvažnija strategija jest da "Europska bankovna unija (EBU) ukloni odstupanja u bankarskom sektoru u eurozoni", dok "zahtjev Basel-a III o nerizičnom omjeru financijske poluge (LR)" ima najmanju važnost među strategijskim prioritetima.
\end{abstract}

Key words: DANP, fuzzy (neizraziti) TOPSIS, strategija, konkurencija, Europski bankovni sektor

JEL klasifikacija: G20, G21, G41, E44

1 Preliminarna verzija ovog rada predstavljena je na konferenciji IFABS, 2016., "Rizik u financijskim tržištima i institucijama: novi izazovi, nova rješenja" (Barcelona, 1-3. Lipnja 2016.). Posebnu zahvalu upućujemo Mauriziou Michaelu Habibu, Thomasu Flavinu, Yener Altunbasu i Nikosu Paltalidisu zbog svojih vrijednih primjedbi i prijedloga.

2 Izvanredni profesor, Istanbul Medipol University, School of Business and Management, Beykoz, 34810, Istanbul, Turska. Znanstveni interes: bankarstvo i osiguranja. Tel.: + 902124448544. E-mail: hdincer@medipol.edu.tr (osoba za kontakt).

3 Izvanredni profesor, Manchester Metropolitan University, Business School, Manchester, Velika Britanija. Znanstveni interes: računovodstvo i financijska ekonomija. Tel.: +44 (0)161 247 3950.E-mail:o.olgu.akdeniz@mmu.ac.uk.

4 Izvanredni profesor, Istanbul Medipol University, School of Business and Management, Beykoz, 34810, Istanbul, Turska. Znanstveni interes: poslovanje i financije. Tel.: + 902124448544. E-mail: uhacioglu@medipol.edu.tr. 


\section{Appendix}

Figure A1: Flowchart of the integrated model for strategy selection

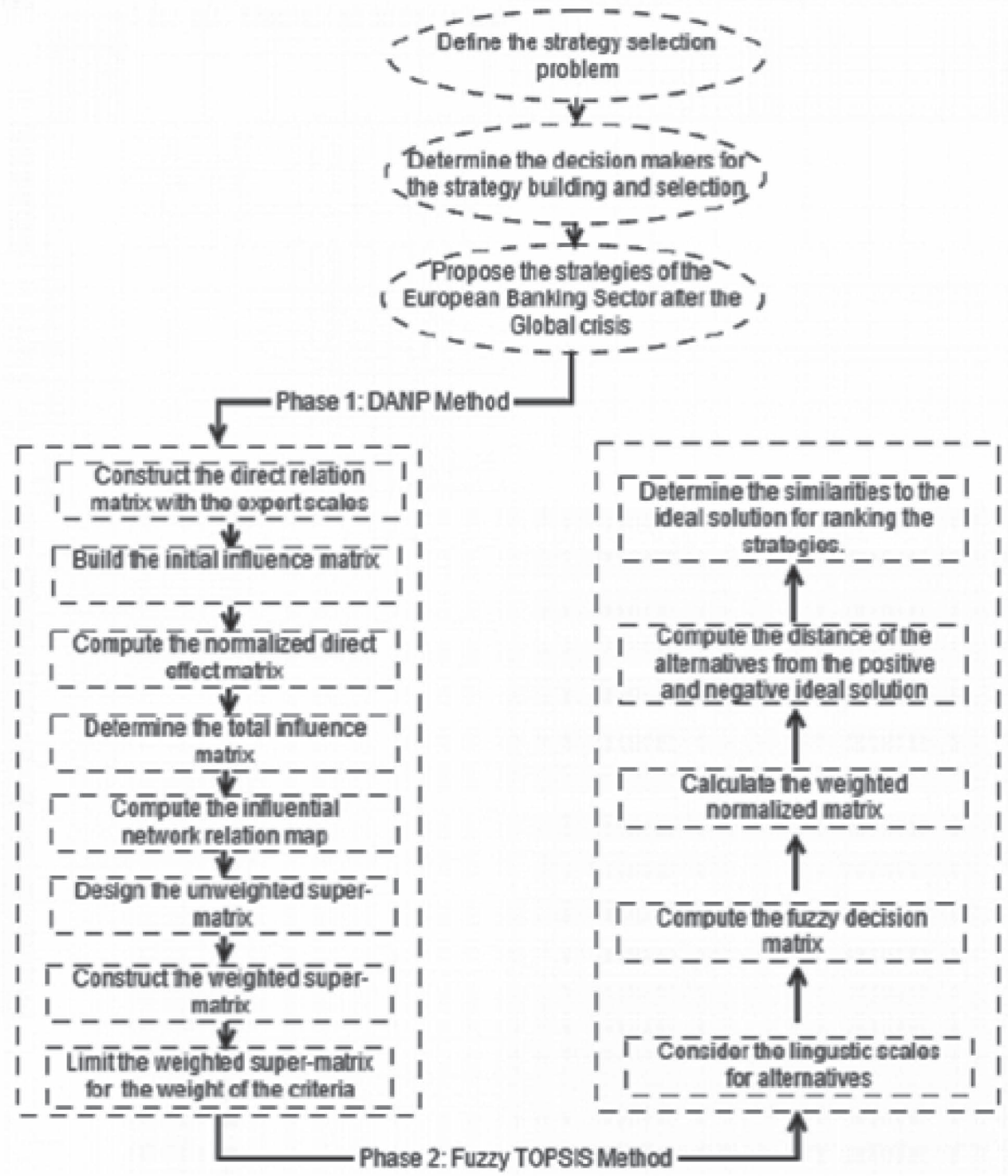

Source: Authors`own figure 